\section{FORT SMITH, NORTHWEST TERRITORIES}

DATE: 26 December 1982

WEATHER: Scattered overcast. Temperature $-23^{\circ} \mathrm{C}$. Snow depth $41 \mathrm{~cm}$.

TRAVEL: 3 groups covered $150 \mathrm{~km}$ in 3.5 hours by car.

BIRDS SEEN: Willow Ptarmigan, 6; Gray Jay, 9; Common Raven, 54; Black-capped Chickadee, 6; Boreal Chickadee, 4; Unidentified Chickadee, 12. Five species, 91 individuals.

OBSERVERS: Kevin Antoniak, Rita Antoniak, Gail Bourke, Mr. Bowes, Don Brannington, Isabel Brannington, Len Hooper, Mrs. Mollie Hooper, Bill Jensen, Lea Jensen, Michael Jones, Harold Pankratz, Jeff Thompson (compiler).

\section{INFORMATION WANTED ON GREAT GRAY OWLS IN SASKATCHEWAN}

As recently as 25 years ago the Great Gray Owl was considered to be very rare and possibly endangered in North America. Recent work by Bob Nero in southeastern Manitoba has proven the Great Gray Owl to be quite common some years in that region. Observations in Saskatchewan over the past ten years indicate that Great Gray Owls are not uncommon in some areas of this province.

I would appreciate receiving information on any unpublished observation of Great Gray Owls in Saskatchewan Please include date, location and habitat in which the observations were made. - Wayne Harris, Box 414 , Raymore, Saskatchewan. SOA 3J0

\section{PRAIRIE NEST RECORDS SCHEME}

Persons in Alberta, Manitoba, Saskatchewan, and the Northwest Territories interested in recording the progress of nesting birds are required to assist the Prairie Nest Record Card Scheme.

Information is entered on the blank nest record cards. The cards are returned to the Prairie Nest Record Scheme when the nesting season is finished. Graduate students, government biologists and other researchers make use of the cards when seeking nesting data on bird species they are studying.

Recording cards, instructions, and a copy of the 1982 nesting season report can be obtained by writing H.W.R. Copland, Prairie Nest Record Card Scheme, Manitoba Museum of Man and Nature, 190 Rupert Avenue, Winnipeg, Manitoba. R3B ON2

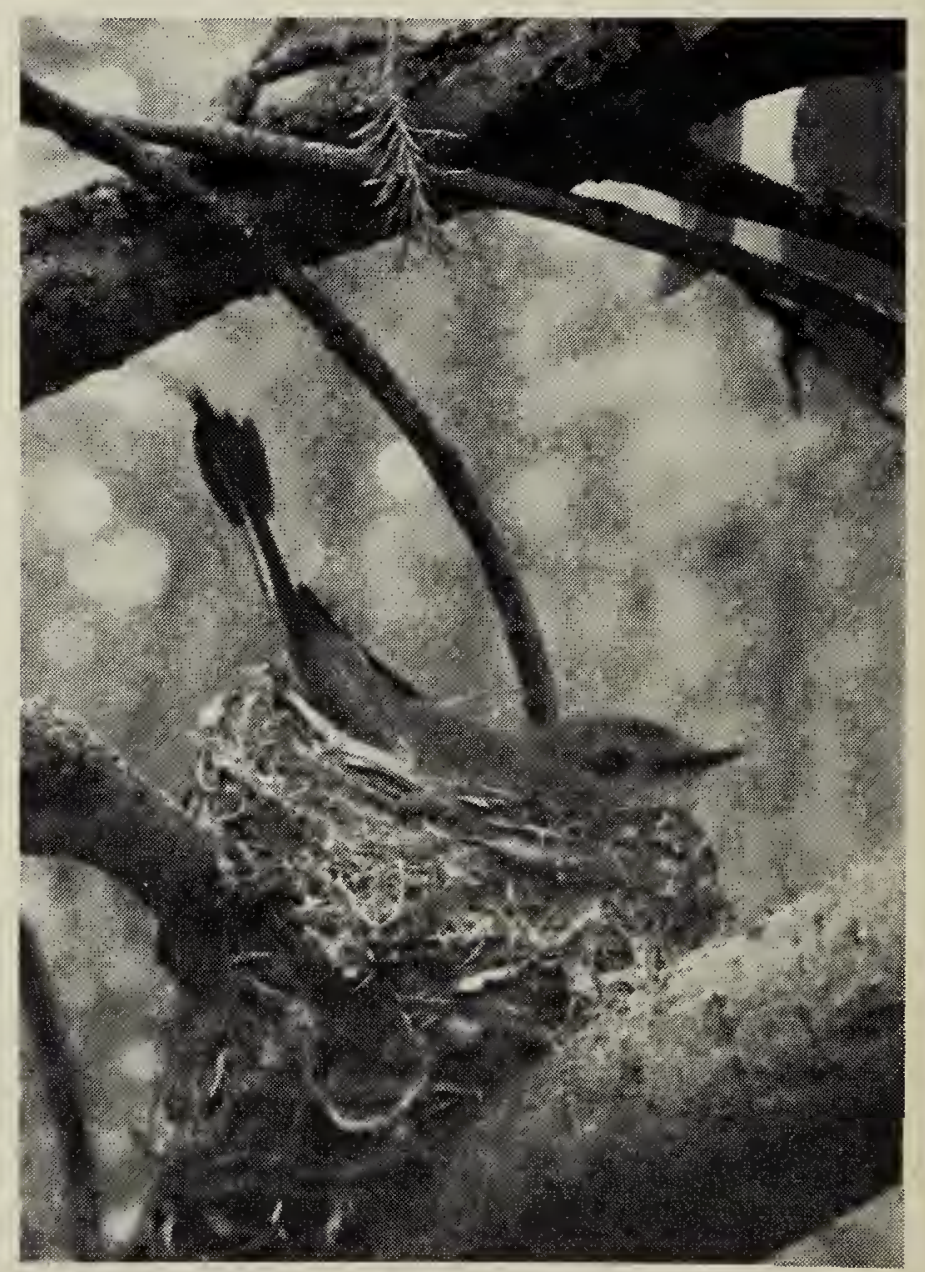

American Redstart on nest

C.J. Smith 